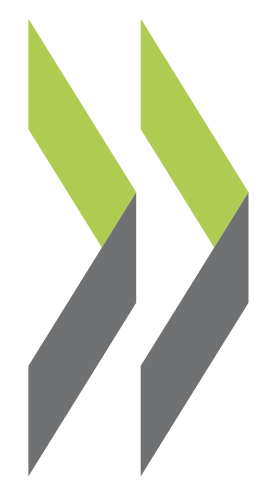

OECD Local Economic and Employment Development (LEED) Papers 2015/01

Local economic strategies for ageing labour markets: Marijampolé's Third Age Simonas Gausas, University in Lithuania 

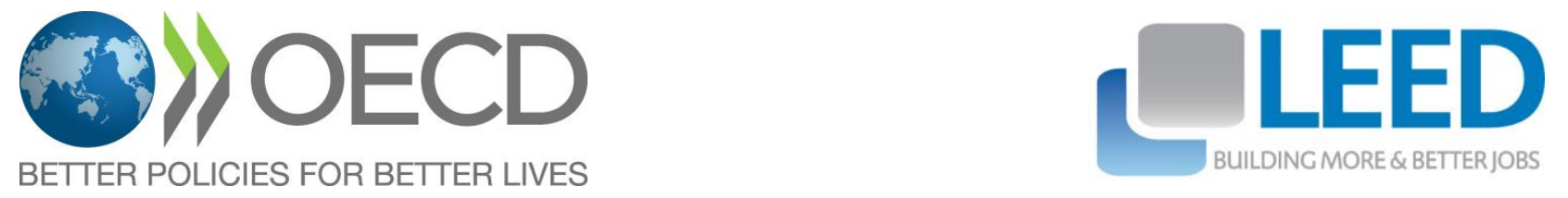

\title{
Local economic strategies for ageing labour markets
}

\author{
Marijampolè's \\ Third Age University in Lithuania
}

Working Paper 
OECD Working Papers should not be reported as representing the official views of the OECD or of its member countries. The opinions expressed and arguments employed are those of the authors.

Working Papers describe preliminary results or research in progress by the author(s) and are published to stimulate discussion on a broad range of issues on which the OECD works. Comments on Working Papers are welcomed, and may be sent to the Centre for Entrepreneurship, SMEs, Tourism and the Local Economic Development, OECD, 2 rue André-Pascal, 75775 Paris Cedex 16, France.

Authorised for publication by Stefan Kapferer, Director, Centre for Entrepreneurship, SMEs, Tourism and Local Development

You can copy, download or print OECD content for your own use, and you can include excerpts from OECD publications, databases and multimedia products in your own documents, presentations, blogs, websites and teaching materials, provided that suitable acknowledgment of the source and copyright owner is given. All requests for public or commercial use and translation rights should be submitted to rights@oecd.org. Requests for permission to photocopy portions of this material for public or commercial use shall be addressed directly to the Copyright Clearance Center (CCC) at info@ copyright.com or the Centre français d'exploitation du droit de copie (CFC) at contact@cfcopies.com. 


\section{TABLE OF CONTENTS}

NATIONAL BACKGROUND AND POLICIES - AGEING LABOUR MARKET IN LITHUANIA..........5

The main national policy measures for addressing the issue of an ageing workforce ................................ 8

AGEING LABOUR MARKET IN THE MARIJAMPOLE DISTRICT - REGIONAL BACKGROUND

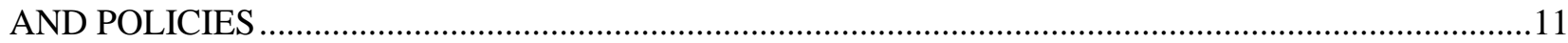

The impact of ageing on labour markets in the Marijampolè region ......................................................11

The main regional and local measures for addressing the issue of an ageing workforce ........................13

LOCAL STRATEGIES FOR AGEING AND SHRINKING LABOUR MARKETS - MARIJAMPOLE'S

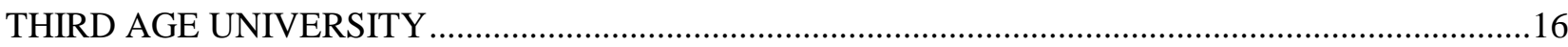

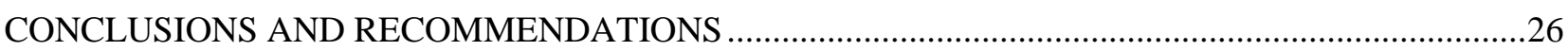

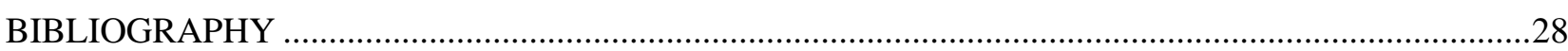

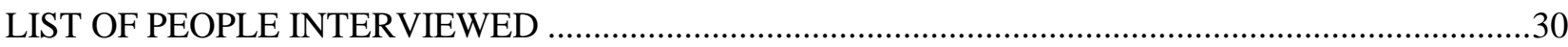

\section{Tables}

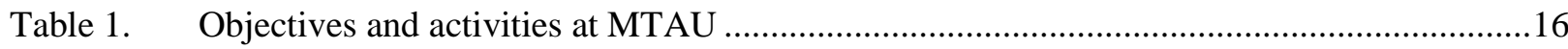

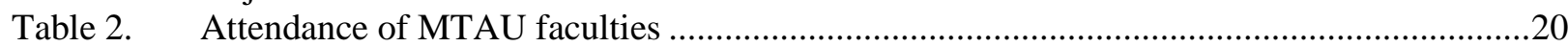

\section{Figures}

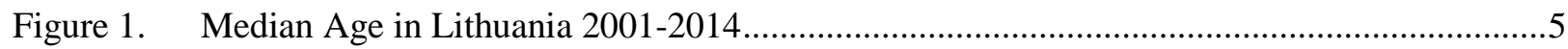

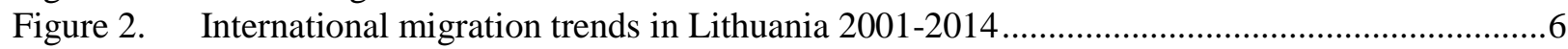

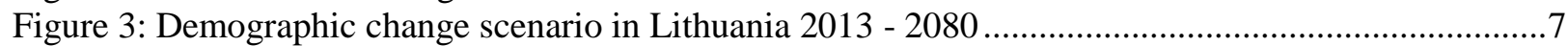

Figure 4: Demographic trends in Marijampolè region in 2001-2014 …..........................................11

Figure 5: International migration effects on the Region of Marijampole in 2001-2014 .........................12

Figure 6: Change in the labour market demand in Marijampole region ................................................12

Figure 7: Participation of unemployed persons aged 50 and above in different ALMP measures, in

Marijampolè region, in January- December 2014, in \% ...................................................................... 14

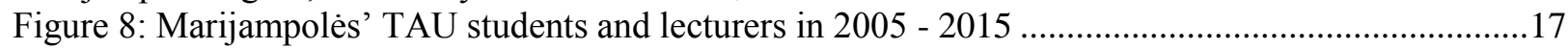

Figure 9: The governance structure of the Marijampolè's TAU............................................................19

\section{Boxes}

Box 1. Education providers involved in initiatives for older workers ....................................................14

Box 2. Experiences of participants in Marijampolè's Third Age University ..........................................22

Box 3. Intensive ICT training for older people in the Marijampolè Public Library ................................24 
This research is carried out as part of the OECD LEED programme project "Local economic strategies for shrinking and ageing labour markets". The aim of this paper is to analyse a local initiative addressing the issue of skills development of an ageing workforce and illustrating how local authorities, training providers, public employment services and/or private companies co-operate on this issue. Older workers in this study are understood as workers aged 50 and above.

The paper starts by examining the broader picture of demographic change in Lithuania and the national policy measures to address this. Next, the paper looks at the demographic trends and related policy measures in the selected region of Marijampole. Finally, the role of Marijampolè's Third Age University (MTAU) in promoting the professional and entrepreneurial skills of older people is examined. The cases of individual learners are used to illustrate the impact of skills gained at MTAU for prolonging working lives. The case of MTAU is further supplemented with another local initiative of Petras Kriaučiūnas Public Library of Marijampolè (Marijampolè Public Library) to provide Information and Communication Technology (ICT) skills for older people. The paper ends with conclusions and recommendations.

This case study was of the exploratory nature. The desk research phase involved analysis of seminal documents and available statistics at national and regional level. The interviews with the representatives of the Municipality of Marijampole, the Territorial labour exchange office of Marijampole and educational institutions were carried out in order to enrich the regional and local picture of an ageing society. In depth non-structured interviews were implemented with the training providers, teachers and learners in MTAU and the Marijampolè Public Library. 


\section{NATIONAL BACKGROUND AND POLICIES - AGEING LABOUR MARKET IN LITHUANIA}

This section briefly discusses the reasons behind the rapid ageing and shrinking of the national labour market of Lithuania. Further, national policy measures to tackle the challenges of ageing, in particular the skills development of older workers, are discussed. This section explores the following questions: how effective are strategic documents which propose a holistic approach to the promotion of longer working lives? Are these strategies reflected in actual labour policies? Who and how implements training and retraining of older workers?

\section{The impact of ageing on labour markets in Lithuania}

Figure 1. Median Age in Lithuania 2001-2014

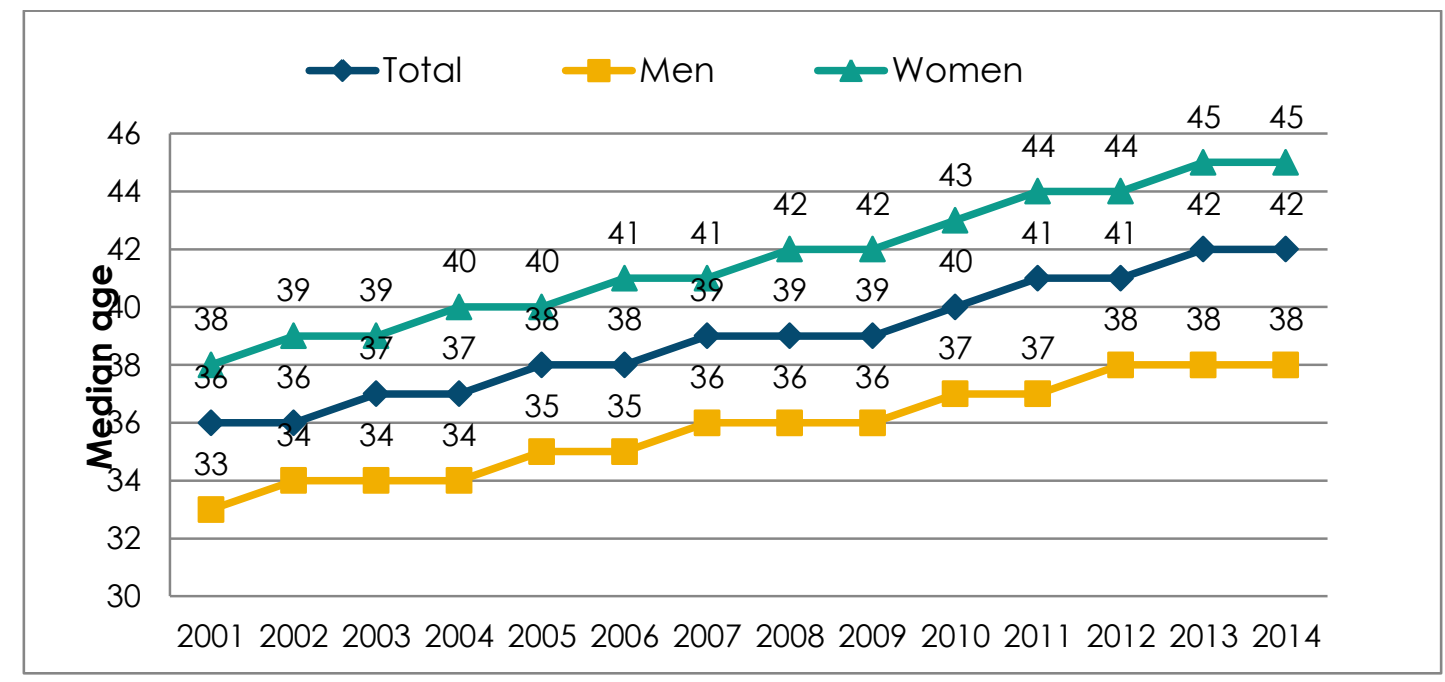

Source: prepared by Visionary Analytics based on Statistics Lithuania data

Lithuania is one of the fastest ageing and shrinking countries in the EU (European Commission, 2012). Whereas life expectancy has increased in Lithuania, the birth and immigration rates remain low and emigration rates of the young population are high. Therefore, between 2001 and 2015, Lithuania's population shrank from 3.5 million to 2.92 million (Statistics Lithuania, 2015).

The median age of women increased by seven years during the period $2001-2014$, and reached 45 years. Although the life expectancy of Lithuanian men is one of the shortest in the EU, the median age of Lithuanian men has increased by five years, and reached 38 years in 2014 (see Figure 1).

In addition, Lithuania is experiencing high emigration rates (see Figure 2). Out-flow migration peaked in 2010 and international net migration rates reached -25.2 per 1000 inhabitants. ${ }^{1}$ In recent years,

\footnotetext{
${ }^{1}$ Statistics Lithuania provide data of persons who declared their arrivals or departures. In 2010, the number of declarations of departures peaked. This coincides with the introduction of an obligatory payment to statutory health insurance for all residents in Lithuania.
} 
emigration has slowed down and immigration (mainly re-emigration) has increased. Nevertheless, net migration remains negative - in 2014 it was only -4.2 per 1000 inhabitants. Negative migration rates cause serious strain as mainly young, working-age people are emigrating from Lithuania. Lithuania is ranked as slightly unfavourable (scoring 37 of 100) to immigrants from Third Countries and the access to nationality is evaluated as slightly unfavourable as well (scoring 35 of 100) (MIPEX, 2014). Recent legislation on the establishment of migrant businesses shows that this index might worsen in the recent years to come.

Figure 2. International migration trends in Lithuania 2001-2014

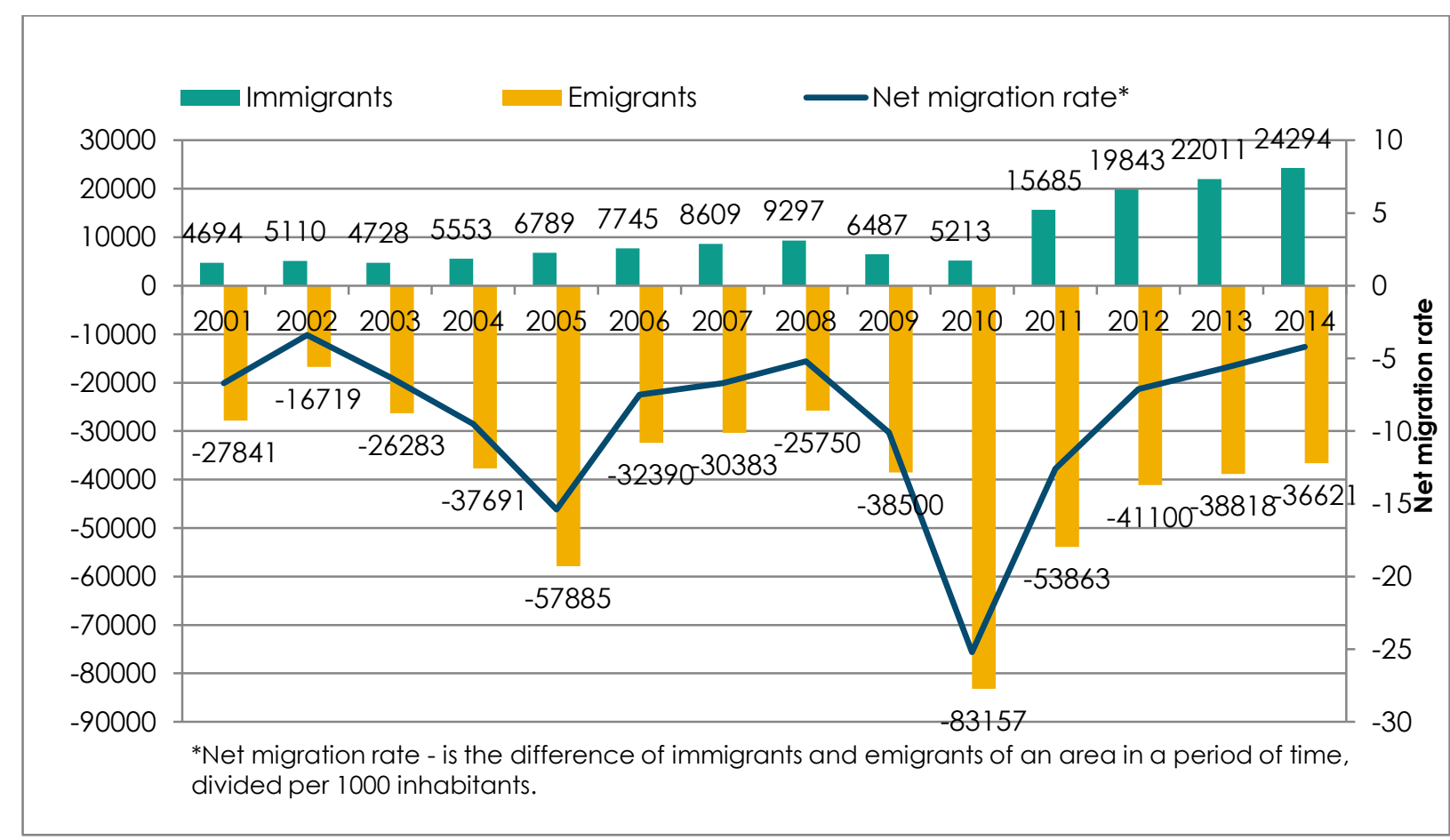

Source: prepared by Visionary Analytics based on Statistics Lithuania data

Forecasted changes to the composition of society in Lithuania are worrying (see Figure 3 ). The Eurostat population projections indicated that by 2040 Lithuania will have less than 2 million inhabitants (Eurostat, 2013). It is expected that Lithuania will experience a doubling of its old-age dependency ratio by 2040 (European Commission, 2015). If Lithuania will not revert or mitigate current trends by, for example, improving birth rates, attracting migrants or encouraging Lithuanians to re-emigrate, a demographic decline of the working age population will create a serious strain on the current social security system, especially on old age pensions. In addition, it is likely that Lithuanian migrants will re-emigrate to Lithuania when they reach the age of retirement, as this has been the trend in other migrant sending countries (Ackers \& Dwyer, 2002). This also presents Lithuanian health, long-term care, and welfare systems with new challenges. Although Eurostat population projections are not without limitations (e.g. an assumption that the same migration flows will continue far into the future is disputable), they send a warning signal to the country. 
Figure 3: Demographic change scenario in Lithuania 2013 - 2080

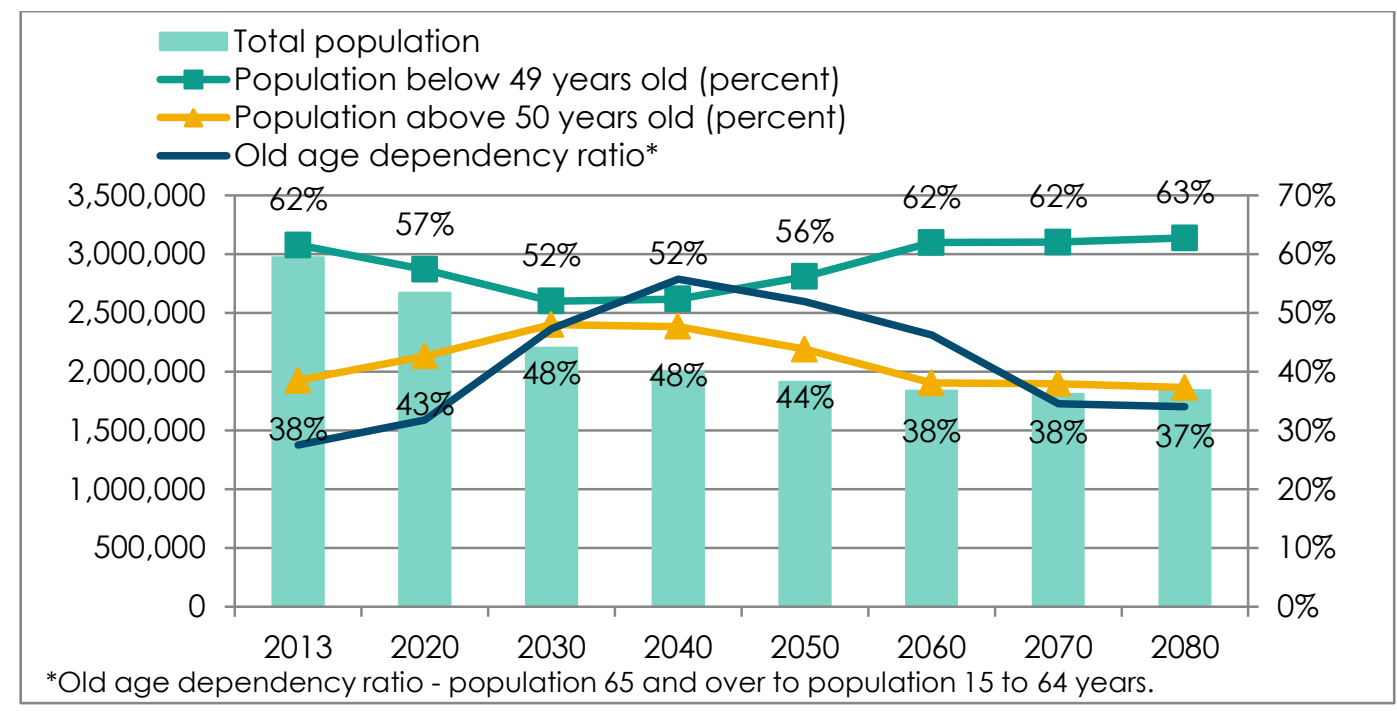

Source: prepared by Visionary Analytics based on Eurostat data.

The European Commission's Ageing Report suggests that Lithuania will suffer from one of the sharpest declines in population in comparison with the rest of the EU (European Commission, 2012). Longer life expectancy should be followed by a considerable increase in employment rates for older people across the EU-27 during the next 50 years (European Commission, 2012). The ageing population will put further pressure on potential growth of the Lithuanian economy. The country needs to manage the transition from a low-cost, low-tech economy to a more skills and innovation-intensive economy (European Commission, 2015). Therefore, it is important for Lithuania to prepare for the up-skilling and re-training of older workers and to keep them active in the labour market.

Currently, older workers in Lithuania are not willing to retire due to low pensions, which are close to the at-risk-of-poverty threshold. In 2013, the at-risk-of-poverty threshold for a single person in Lithuania was EUR 234 per month and the average old-age social security pension was EUR 246 per month (European Commission, 2015). There are limited financial possibilities for older people to harness their skills. In addition to low income, there are other external factors hindering re-training, such as poor health and discrimination against older workers in the labour market. The internal factors, such as lack of motivation and low self-esteem also need to be addressed by national policies focusing on the ageing society.

In a nutshell, Lithuania is experiencing rapid population ageing and sharp decline, which is exacerbated by the out-migration of the working age population. By 2040, old-age dependency will peak. This trend will create a strain on the current social model and economy of the state. Therefore, it is a matter of urgency to promote active ageing and to enable older workers to contribute to society. Currently, the older population is 'pushed' into working longer due to the risk of old age poverty. However, the training and re-training of older workers is still considered as an exception rather than a rule in Lithuania. The next section will discuss policies to promote active ageing in general along with the training of older workers more specifically. 


\section{The main national policy measures for addressing the issue of an ageing workforce}

In this context, better harnessing the skills of older workers becomes crucial for national policies. Several measures have already been set up or are currently under review to address the issue of an ageing workforce: relevant amendments of the Labour Code and the Law on Support for Employment, proposed measures of the Social Model and Active Ageing programme, active labour market policy (ALMP) measures of the Labour Exchange Office and an exemplary project funded from the European Social Fund, which promotes the employability of older workers.

- Relevant provisions of the Labour Code. The Labour Code of the Republic of Lithuania contains certain guarantees for older workers upon dismissal. The Termination of an Employment Contract on the Initiative of an Employer without any Fault on the Part of an Employee protects persons who have not more than five years before their old-age retirement (Article 129). The Labour Code also includes the Right of Priority to Retain the Job in the Case of Redundancy for persons who will be entitled to the old-age pension in not more than three years and for persons who have been working in the company for 10 consecutive years (Article 135, para. 4 and para. 3). The law also protects persons who take care of old-age pensioners with intermediate level of disability (more than $55 \%$ of incapacity) (Article 135, para. 2). Additions to salary are paid in some enterprises (mainly in the public sector) for years of service along with a system of longer annual leave (Zabarauskaite \& Blaziene, 2014).

- Relevant amendments to the Law on Support for Employment. The Law on Support for Employment, which was amended in July 2014 foresees that:

- Persons above 50 years old are additionally supported (Art. 4, para. 7).

- The article on Supported Employment measures besides subsidised employment, support for acquisition of job skills, job rotation and public works has introduced a new measure - skills acquisition agreement (Art. 24).

- Skills acquisition foresees the possibility for unemployed persons to make a bi-partite agreement in order to acquire skills in a certain company. This is relevant for persons above 50 years old, as thanks to a new ESF project, they can undertake such measures to gain labour market skills, for example in a new profession.

- Employers may receive larger financial incentives for nominating experienced employees, aged above 50, to act as tutors for newly employed staff (aged less than 29 years old).

- In addition, there are supplementing provisions included in the Law on the Support for Unemployed Persons. They foresee better social protection of older unemployed persons upon losing a job.

- Relevant policy changes proposed in the Social Model project. As of 2014, the expenses of the State Social Insurance Fund Board under the Ministry of Social Security and Labour (SODRA) budget had been exceeding its revenues for seven consecutive years. This means that a share of pensions and other benefits are annually paid from borrowed funds. The government of Lithuania therefore intends to revise its "social model", which would also include a proposal on comprehensive pension system reforms, employment, labour relations and actions against poverty. This reform includes pension indexation rules and an increased pensionable age after 2026. There are proposed amendments to the Labour Code, such as the possibility to dismiss 
older persons more easily and to shorten their notice periods. On the other hand, the proposed Social Model foresees the possibility for flexible working schedules and remote working. In addition, the Life-Long Learning provision includes the free time for employees to participate in training and is encouraging employers to pay for the time spent in training. Older unemployed people are explicitly targeted as one of the most socially vulnerable groups in the proposed package on employment. Older people and people with disabilities will have the possibility of being employed via pre-paid service vouchers. In addition, ALMP measures on life-long learning and re-training are encouraged. However, the current proposal outlines plans to abolish subsidies for covering self-employment under business license as the ALMP option. Measures to tackle poverty target the improvement of social inclusion programmes and services for older people (Social Model, 2015). Abovementioned proposals were referred by the Government to the Lithuanian Parliament (Lit. Seimas) for approval.

- Relevant actions in the Programmes for Active Ageing. The National Strategy for Overcoming the Consequences of Ageing was implemented in the period 2005 - 2013. The main outcomes on employment are as follows: training on entrepreneurship for persons of over-fifties; opportunities to start individual entrepreneurial activities under business license; creation of a contact bank for retired persons who are willing to work; special vocational training modules; and opportunities for distant training. In 2014 - 2015, this programme was replaced by the National Demographic Policy Strategy Plan, which outlined financial support to the NGOs representing older people (Minister of the Social Security and Labour, 2014). The projects are expected to begin in 2016 and to run for four years. The foreseen measures aim to promote adult learning and adapt the working environment to the needs and requirements of older staff members, at both national and company levels.

- Relevant measures for Older Unemployed Persons implemented by the Lithuanian Labour Exchange. In 2003, the Lithuanian Labour Exchange started the first ALMP measure "55+" targeting people above 55 years old. This measure aimed to improve the employment situation for the people of pre-pension age. In January 2015, the Lithuanian Labour Exchange started a new project - "Support of Older Unemployed Persons" (European Social Fund, 2014). Therefore, as well as subsidies for older unemployed people, the new project proposes an option for the vocational training and re-training of those over 54. In addition, it tackles the issue of immobility of older unemployed people in the labour market by reimbursing their commuting costs.

- Exemplary projects funded from the ESF. A few projects co-funded by the European Social Fund (ESF) are aimed at the skills development of older workers. For example, the project "Development of the adult education system by providing key competencies to learners" (phase II) 2012 - 2014. The Education Advancement Centre (Lit. Ugdymo plètotés centras) is implementing this project partly funded by the ESF and the Ministry of Education and Science (MES). The project has covered the majority of regions in Lithuania, including the Marijampole region. It targeted adult learners (especially above 54 years old), adult education institutions, management representatives, adult educators ("andragogues") and other adult education personnel. The project foresees the following results that are relevant to the longer working lives of the Lithuanian workforce: acquiring or strengthening general and professional competencies, continuous learning skills; broadening opportunities in the labour market and public life. In addition, the project aimed to strengthen the capacity of adult education institutions to provide innovative educational programmes in the regions, to create new regional development guidelines and to improve substantially in adult education planning and monitoring (EU Support Website, 2011). 
- Network of Third Age Universities in Lithuania. The first Third Age University (TAU) in Lithuania was registered in 1995. The TAU is one of the fastest growing organisations in Lithuania. In 2012 there were 24 TAUs active in different towns across Lithuania. In 2014, there were 40 active TAUs across Lithuania (Kalvaitis A., J. Barauskiené, A. Mačènaite, 2014). If the current tendencies remain, the TAU will become one of the main channels for reaching out to the rapidly ageing population in Lithuania. The Lithuanian TAU model has differed from its counterparts in Germany and elsewhere, as it is a broader social and cultural organisation for older people. Among the initial objectives of the TAU were the promotion of active ageing and longer participation of older people in the labour market. Article 2.6. of the Statute has outlined that "promotion of sport and physical education is used as the best means to maintain health and the working capacity". Nevertheless, in Lithuania the TAU channels are underused in promoting labour market skills among older people.

To conclude, national policies are identifying the need to retrain older workers, however the practical response is rather weak in terms of developing the skills of these workers:

- Existing broad range measures are either passive or counterproductive.

- The Labour Code contains provisions that prohibit the dismissal of older employees of prepension age.

- The over-fifties are one of the main target groups in the Law on Support for Employment. The new version of the Law (January 2015) included the following group-specific measures: providing vocational training and supporting mobility and acquisition of labour market skills.

- The new Social Model project (a package to revise the current national social security system) and Active Ageing strategies do not propose practical measures for harnessing labour market skills among older workers. They focus, rather, on increasing the age of retirement.

- Retirement or disability policies are counter-productive as they hinder the entrepreneurial activities of older people. For example, various tax benefits, subsidies or tax allowances are reduced or cancelled if a person engages in some economic activity. Therefore, people of retirement age are discouraged from taking personal initiative at an older age.

- Projects funded by the ESF rarely target older workers (excluding Labour Exchange co-funded projects). The initiative of the Education Advancement Centre on the acquisition of general skills among older workers is an exception. This project highlighted the need to better match older people's education and training needs.

- The development of the TAUs in Lithuania was a bottom-up initiative. However, the TAUs do not understand their role in providing labour market skills for older people. Instead, TAUs are portrayed as institutions organising leisure activities for retired people. In turn, TAUs are not included as key partner institutions in Active Ageing plans. This misperception will be further analysed in the subsequent sections. 


\section{AGEING LABOUR MARKET IN THE MARIJAMPOLE DISTRICT - REGIONAL BACKGROUND AND POLICIES}

In Lithuania, there are two levels of governance: national (centralised) and municipality (autonomous ) level. Thus, regions are not separate administrative units. The municipalities of respective regions follow national strategies regarding ageing, Labour Code etc. The Territorial Labour Exchange Offices are the main institutions providing training and retraining for unemployed adults in the Lithuanian regions. They follow the decisions of the Labour Exchange with slight adjustments to the local situation. This chapter provides statistics on ageing and its impacts on the labour market in the Marijampole region. The policy measures addressing this challenge at the municipal level are briefly discussed.

\section{The impact of ageing on labour markets in the Marijampolė region}

The Region of Marijampole is situated in the South-West of Lithuania. Five municipalities of Kalvarija, Kazlų Rūda, Marijampolè, Šakiai and Vilkaviškis make up the region. The regional demographic trends between 2001 and 2014 were similar to the rest of the rural regions in the periphery of Lithuania, excluding the big cities of Vilnius, Kaunas and Klaipeda, where unemployment rates are below the national average. The Region of Marijampole has experienced the following:

- The total population has shrunk by almost 34700 , which makes up $23 \%$ of the total population (154,000 as of 2014) (see Figure 4);

- The negative net international migration is accountable for $60 \%$ of total shrinkage ora loss of 20 800 residents (see Figure 5);

- The remaining $40 \%$ is due to negative natural population growth. As of 2014 , annual death rates exceeded birth rates by one third and to sum it up, there was a loss of 761 person, in the Region of Marijampolè (Statistics Lithuania, 2015);

- During recent years the old age dependency ratio has actually shrunk slightly, however, in the forthcoming decades the situation will come under pressure as birth rates have decreased by $8 \%$ (See Figure 4).

Figure 4: Demographic trends in the Marijampolè region 2001-2014

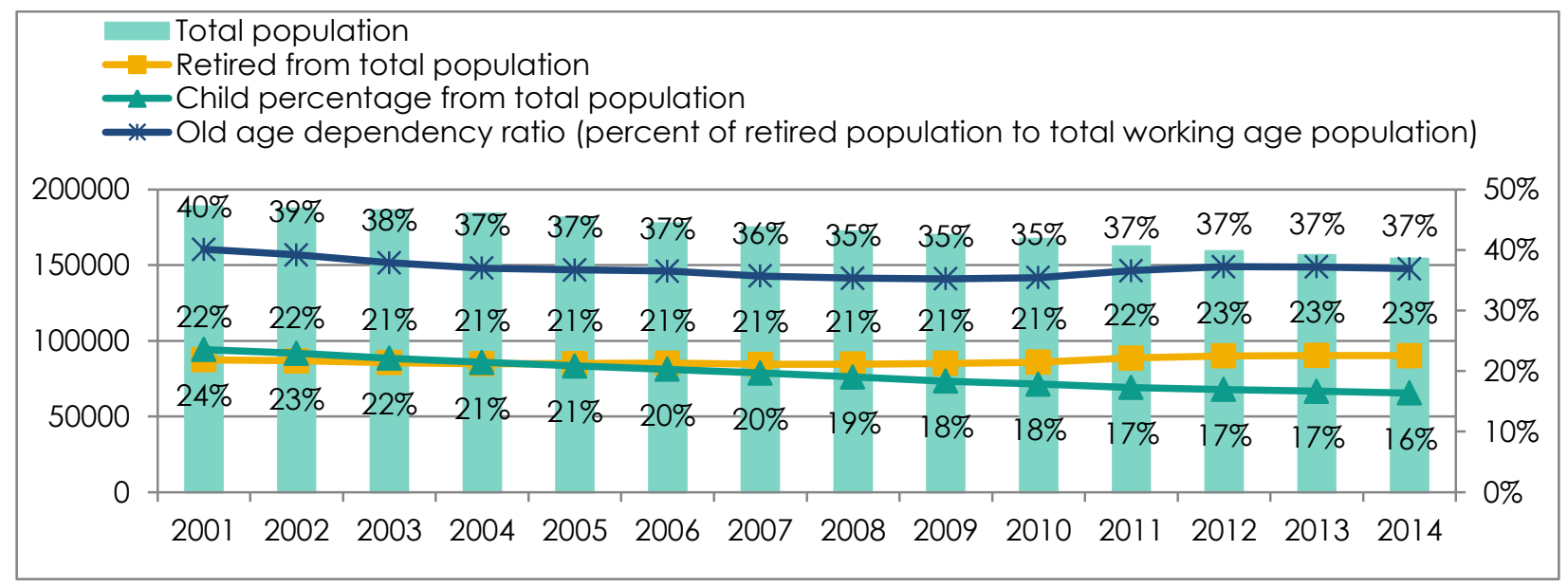


Figure 5: International migration effects on the Region of Marijampolè in 2001-2014

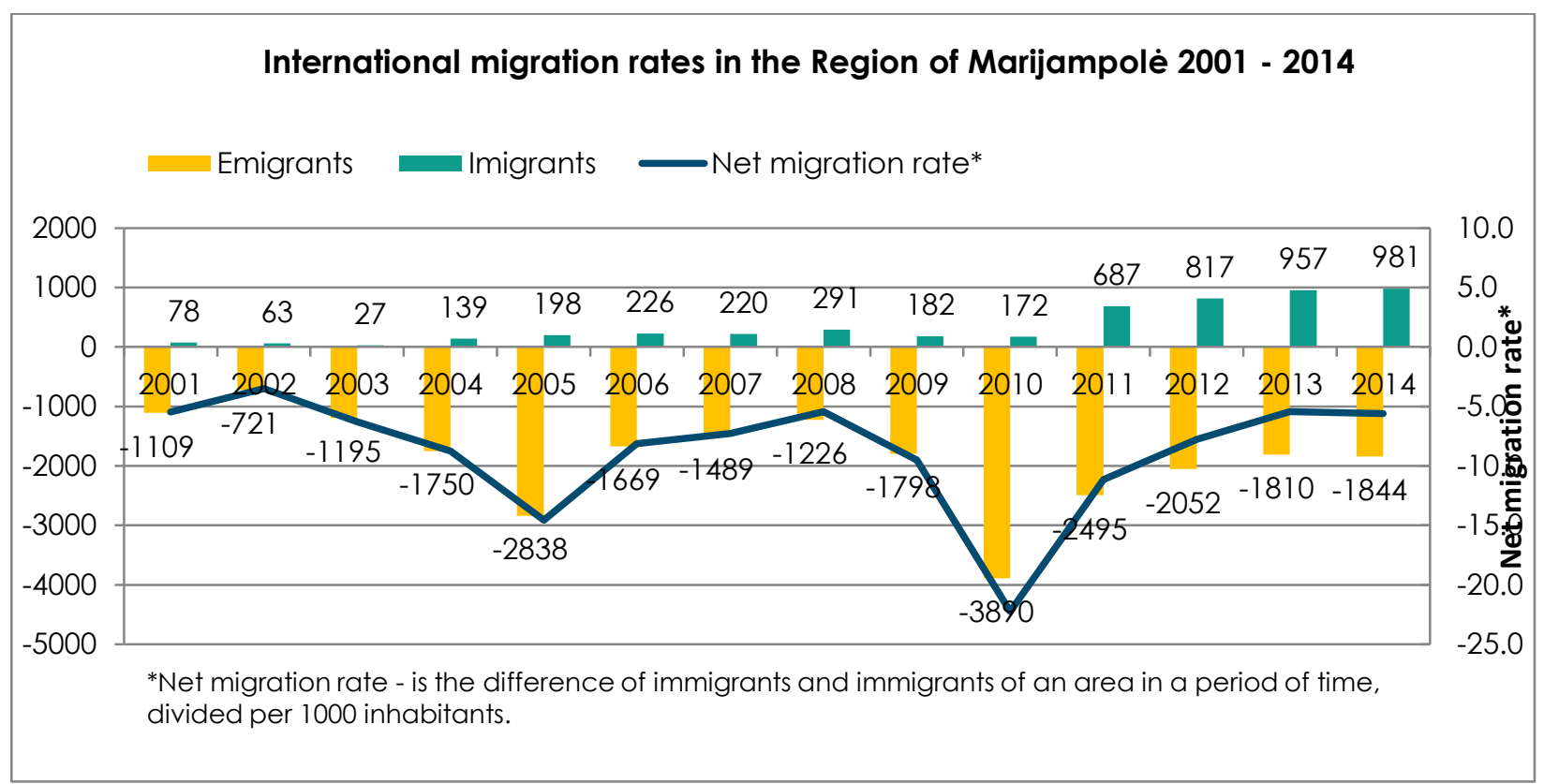

Source: prepared by Visionary Analytics based on Statistics Lithuania data.

As of 1 March 2015, the unemployment rate in the Marijampole region was 11.4\%. 10700 unemployed persons were registered by the Territorial Labour Exchange of Marijampolè. One third of all unemployed persons were above 50 years old (3 737 in total). In 2014, 1147 older unemployed persons entered employment: one third of them with fixed-term contracts, the remaining two-thirds with permanent labour contracts. In 2014, 950 persons over 50 years old started their activities under a business license. In 2014, in the Marijampole region, the highest labour market demand (half of all vacancies) was estimated in the services sector. One in four vacancies was registered in the industry sector, and one in ten in the construction sector (see Figure 6).

Figure 6: Change in labour market demand in Marijampolè region, 2014

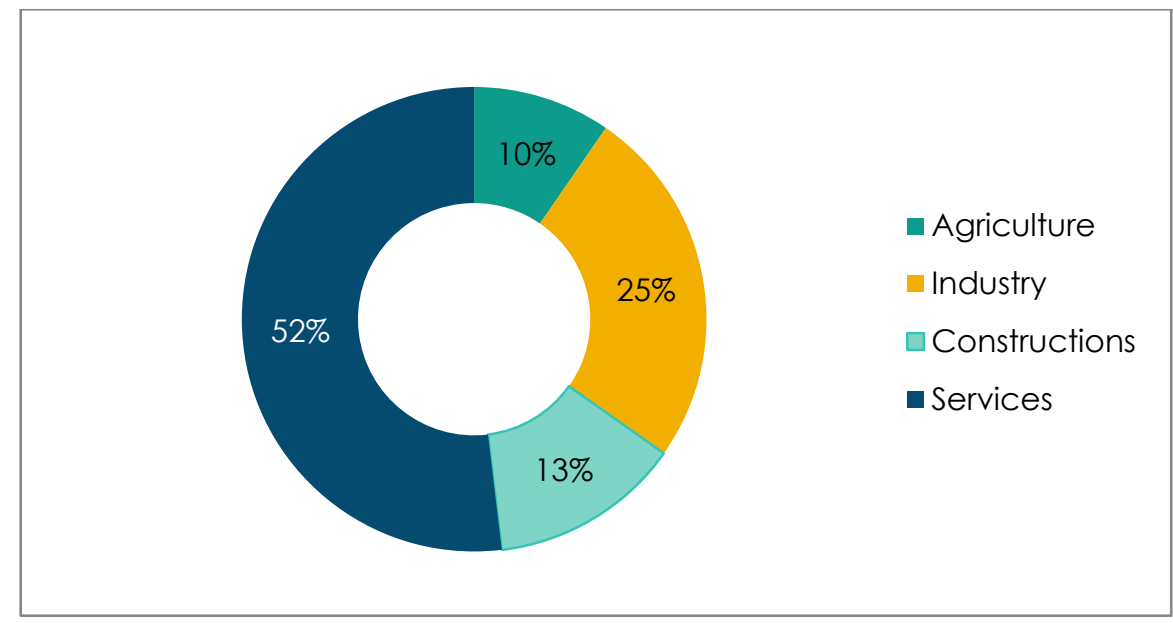


All in all, Marijampole is representative of wider tendencies of internal and international outmigration in the Lithuanian provinces, i.e. the working age population moving to bigger cities in Lithuania or abroad to find jobs. Older people and youth are over-represented among the unemployed. However, employers are more reluctant to employ older people.

\section{The main regional and local measures for addressing the issue of an ageing workforce}

This section examines regional and local measures in the context of ageing workers in the Region of Marijampole and more particularly in the Municipality of Marijampole. It provides examples of local initiatives and their partnerships with local authorities, the labour exchange office, formal and non-formal training providers.

\section{Municipality of Marijampolè's city}

There are no specific initiatives carried out by the municipality to harness the labour market related skills of an ageing population. In addition, the role and responsibility of municipalities in the implementation of the Law on Non-formal Adult Education (2015) is not yet clarified (as the law is very recent). Therefore, it seems that the main actors in this field are the following: the Territorial Labour Exchange Office of Marijampole, educational institutions, especially those providing continuing vocational education and training (CVET), and organisations which are implementing separate projects in the region.

\section{Territorial labour exchange office of Marijampole}

In 2014, 900 persons aged over 50 years participated in various ALMP measures (see Figure 7). The new labour market measure "Support of Older Unemployed Persons" commenced on 1 January 2015. It has provided new opportunities for people over 50 to be trained within a certain demanded profession. Older unemployed people are showing increasing interest in this new option. 
Figure 7: Participation of unemployed persons aged 50 and above in different ALMP measures in the Marijampolè region, January- December 2014, \%

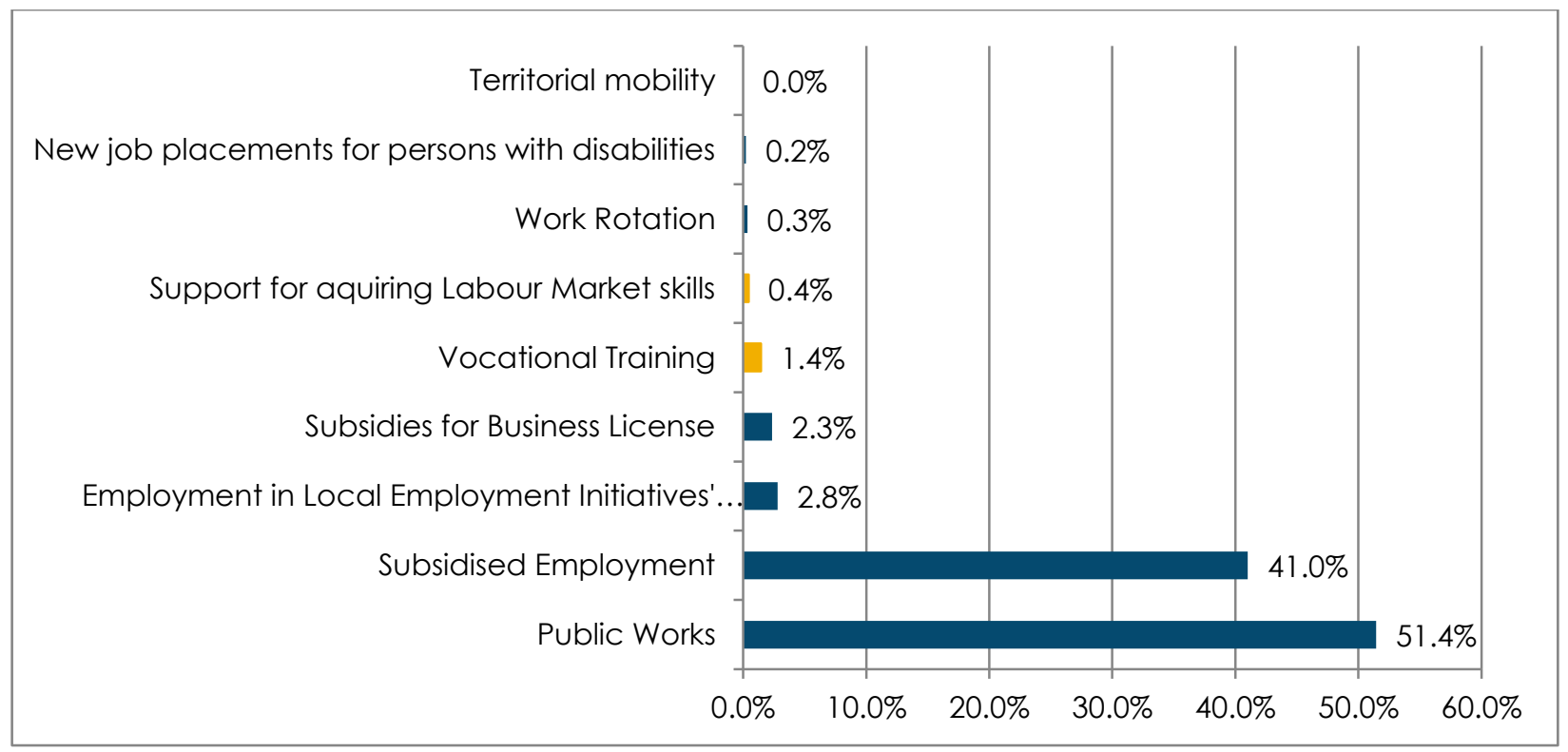

Source: prepared by Visionary Analytics based on data of the Territorial Labour Exchange Office of Marijampolè.

The Labour Exchange Office intermediary, working directly with employers, highlighted that employers are not willing to employ people aged over 45 years. Employers think that older people are at a disadvantage when it comes to communication skills, ICT skills and foreign language skills, mainly in the hospitality sector where there is the highest number of vacancies. It is presumed that older workers work at a slower pace and have lower capabilities for fast learning. They employ older workers only when there is no other option. The lack of young employees is particularly evident in the construction sector.

In the construction sector there is a generation gap as the majority of construction workers are over 50 years old. The construction workers are released each winter and thus the situation is very unstable for older workers. They know that they will be re-employed only if no younger employees are found to fill their jobs. Therefore, it is necessary to change the mentality of employers and to ensure good working conditions for older workers. Other professions popular among older workers include metalworker and long-distance driver. Older people are willing to commence self-employment under a business license in the sectors of construction work and sewing.

Several training providers are also involved in initiatives targeted at older workers (see box 1).

\section{Box 1. Education providers involved in initiatives for older workers}

Development Study Centre, Marijampolès Kolegija (University of Applied Sciences, further Marijampolè College) seminars;

- Provides training for social workers and social work assistants of 40 academic hours divided into five seminars; 
- $\quad$ Approximately half of social work assistants are aged over 50 ;

- Social work is increasingly popular due to the ageing population in the region;

- The majority of trainees are sent on courses by institutions in the region of Marijampolé;

- $\quad$ Some older people who are willing to work abroad attend the courses at their own expense.

\section{Marijampolè College}

- $\quad$ Fewer students over 50 years old than several years ago;

- Older workers come to study when they are in need of certain certificates for their work activities, mainly farmers, social workers and accountants.

- $\quad$ People are not willing to cover their education expenses as other providers, such as local community activity groups, NGOs, and consultancies offer similar project-based training for free and therefore compete with the college;

- Respondents said that the over-supply of training may have the opposite effect than intended, i.e. people are losing motivation to find the training best suited to their needs, instead choosing the training that is provided for free.

\section{Meilès Lukšienès Education Center of Marijampolè}

- Implements project "Development of the adult education system by providing key competencies to learners (phase - II)" in the region of Marijampolè; adults;

There were courses on ICT skills, literature, English language, healthy lifestyle, and road safety for older

- In Marijampolè, the centre co-operated closely with the MTAU to provide a module on "healthy ageing".

\section{Marijampolè Vocational Training and Education Centre}

- Marijampolè Vocational Training and Education Centre provides courses leading to skills and qualifications for young people as well as for adults;

Exchange Office;

license;

Only a small percentage attend to study at their own expense, e.g. tractor-drivers who are in need of a

- The most popular professions at the centre among people aged over 50 include: shop assistant, baker, tailor, metal cutter, and wood-worker. These are also professions in demand, as the respective sectors are well developed in Marijampolè;

- In 2015, the centre received one person according to the ALMP measure for Older Workers (project funded by the European Social Fund).

Source: Visionary Analytics based on interviews with administrator of the Department of Training for Construction and Mechanics, at the Vocational Training Center of Marijampole; Officer responsible for Adult Education at the Department of Education, Municipality of Marijampolè; Project co-ordinator of the Support for older unemployed persons in the Territorial Labour Exchange Office of Marijampolè; Specialist at the Meilès Lukšienès Education Center of Marijampolè; Co-ordinator at the Center of Continuing Studies, Marijampolè College; Vice-director for Education Affairs at Marijampolè College. 
In conclusion, the demographic trends in the region of Marijampole are significant due to the internal migration to larger national cities (rural - urban migration) and international emigration. The regional labour market is experiencing a constant shortage of workers, especially in the services sector. However, people aged over 50 are employed only when younger workers are not available (this is frequent practice in the construction sector, for example). In the Region of Marijampole, as elsewhere in Lithuania, local policies targeting older unemployed people are mainly directed by policies at national level. The territorial labour exchange office is the main institution in the region providing labour market skills for older unemployed people via training and re-training at regional educational institutions and labour market training centres. To a lesser extent, employers send their older employees for training at their own initiative. Research showed that the number of older people studying at their own cost has shrunk in local formal educational institutions (Marijampole College, VETs in Marijampolè). There are some top-down project-based initiatives implemented to address the vocational skills of older people. For example, the Meilès Lukšienès Education Centre of Marijampolè delivered training courses as part of a nationwide project.

\section{LOCAL STRATEGIES FOR AGEING AND SHRINKING LABOUR MARKETS - MARIJAMPOLE'S THIRD AGE UNIVERSITY}

This section provides detailed case studies on Marijampolè's Third Age University (MTAU), as well as the Marijampole Public Library's ICT courses, as local strategies for addressing the ageing labour market challenges in the city of Marijampole and beyond.

MTAU was established in 2005 as a branch of the first Lithuanian TAU of Medardas Čobotas. MTAU activities began in close co-operation with Marijampolè College (Lit. Marijampolès kolegija). The former director of the College officially established and provided the venue for MTAU free of charge. In 2007, MTAU was registered as an independent association. There were three founders, one of whom is the current director - Ms Ona Sakalauskienè.

The 2007 MTAU became an educational, non-profit organisation, uniting older people, those with disabilities and their carers, without age or educational census (The Statute of Marijampolè's TAU, 2007). However, after the first year, an age census was introduced for people without disabilities, which stated that they should be at least 50 years old. Thus, MTAU provides non-formal education for older people and people with disabilities to satisfy their social, cultural and psychological needs (Marijampole's TAU Strategy, 2015). For detailed objectives see Table 1.

Table 1. Objectives and activities at MTAU

Educational

Type of Objectives:

Social

Cultural

\section{Respective Activities:}

Public lectures, seminars, conferences, study visits, workshops, other non-formal education activities;

Involvement of people with disabilities, older people in poverty, within activities; Celebration of national holidays, participation within various cultural events, excursions to foreign and Lithuanian cities; 
Psychological

Promoting health and wellbeing among older people

Source: Prepared by Authors, based on interviews
Providing space and time for socialising, events, co-operation with members of other organisations:

Physical exercises, physiotherapy, lectures on health and prevention of illness.

The rapid growth in numbers of MTAU students was a phenomenon in Marijampole. Currently, it is the second largest TAU in Lithuania. In 2015, there were 746 persons attending the TAU in Marijampole. This figure includes registered students but not persons joining events or lectures on an ad-hoc basis. This means the number of participants in MTAU activities is even larger.

In 2013-2014 the number of MTAU students decreased slightly, as separate TAUs had been established in Kazlų Rūda, Kalvarija and Vilkaviškis municipalities (See figure 8).

Figure 8: MTAU students and lecturers 2005 - 2015

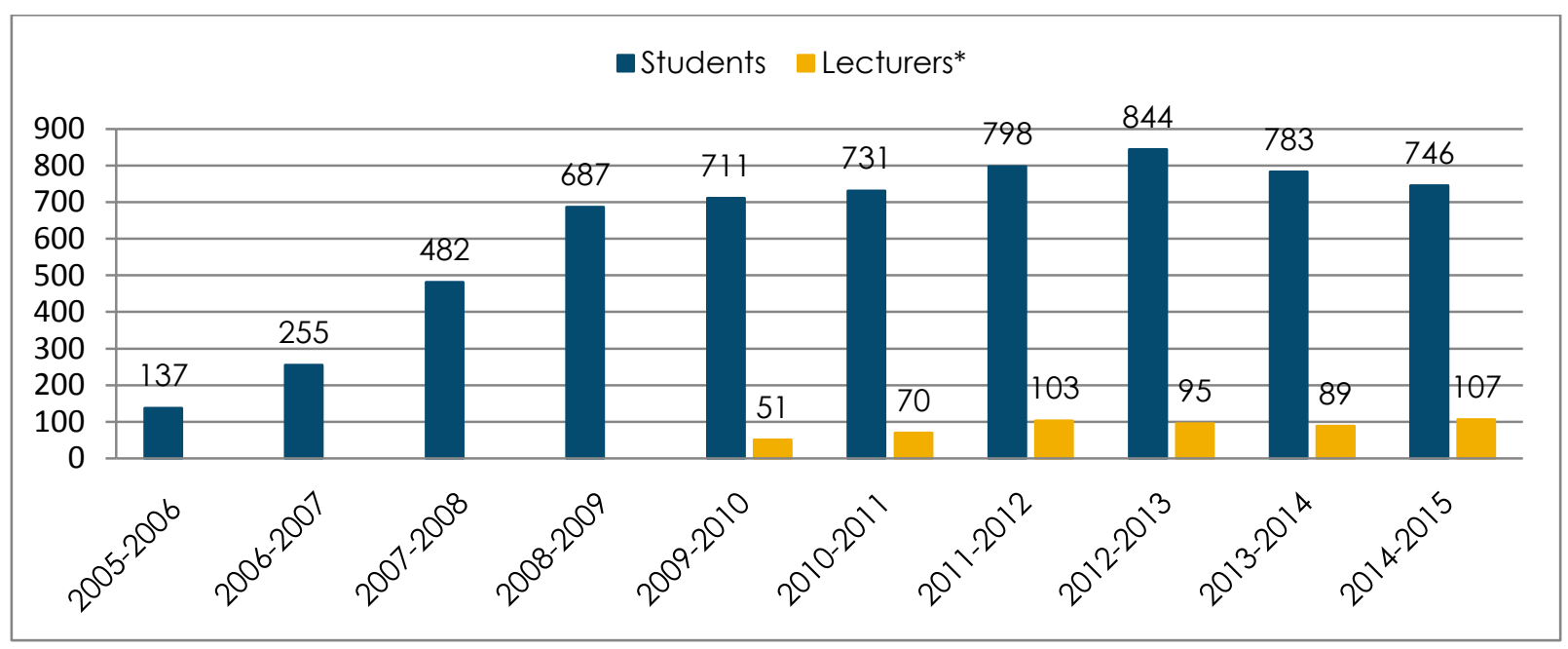

Source: prepared by Visionary Analytics based on data provided by MTAU.

The majority of MTAU students are retirees, who used to work in the field of education and who are living in the town of Marijampolè:

- Only one third of all TAU students are in the labour market; two thirds are already retired.

- The majority of TAU students are/were pedagogues or educators. Other professions include medical and agricultural specialists.

- $70 \%$ of older people are residents in the municipality of Marijampolè. The remaining $30 \%$ come either from rural areas of the Marijampole district or from other towns in the Marijampole region: Šakiai, Vilkaviškis, Punskas, Kazlų Rūda, and Kalvarija.

The number of lecturers continues to grow (see Figure 8). This number includes both permanent lecturers and visiting speakers. For example, in 2015 there were 29 permanent lecturers - deans and vicedeans at MTAU, whereas the remaining 78 were visiting lecturers. The director explained that guest speakers are willing to deliver lectures at MTAU from across Lithuania, for example, professors from the universities of Kaunas, Vilnius and Klaipeda, Members of the Lithuanian Parliament, etc. 


\section{Partners involved in MTAU activities to promote longer working lives}

MTAU has developed a broad network of partners including the following actors:

- Municipality of Marijampolė. The Municipality of Marijampole provides political and financial support for MTAU. Annually, MTAU submits on average four projects for municipality funding. The projects are related to the promotion of health and well-being among older people, inclusion of people with disabilities, social and cultural events for MTAU students, and environmental projects. The director of MTAU indicated that, so far, there was no instance of projects not being selected for funding. The funding is inter-related with the political support of the municipality. For example, the Mayor and Vice-Mayor of Marijampole provide political backing and support to MTAU. They acknowledge the MTAU role in the non-formal education of older people. MTAU has developed a close relationship with the Department of Social Affairs. Furthermore, MTAU co-operates with the Department of Education, Culture and Sport of the Municipality of Marijampolè.

- Educational and other institutions in Marijampolè. MTAU has strong co-operation ties with various educational and other institutions in Marijampole, because the majority of MTAU deans and students are or were working within these institutions. The main benefits from co-operation are organisational support and venues for activities. Organisational support is provided by the following institutions: Meilès Lukšienès Education Center of Marijampolè, Adults' Education Center of Marijampole and Public Health Office of Marijampolè. The main partner in organising activities is Meiles Lukšienès Education Center of Marijampolè, as one of the employees, who is responsible for the education of adults at this centre, helps to organise MTAU activities as part of her daily functions. The Marijampole Adult Education Center provides formal continuing education for adults and co-operates on projects related to labour market skills acquisition. The Public Health Office of Marijampolè sends its employees to give lectures on physical activity, physiotherapy and healthy lifestyles.

- Venues for MTAU activities are also provided thanks to close co-operation ties with Marijampolè College, other education institutions, the cultural house and Marijampole hospital. Marijampole College has provided a venue for MTAU since its establishment in 2005. The majority of the university's activities take place within the Department of Pedagogy at Marijampole College. The ICT courses used to take place within the Faculty of Technology and Business at Marijampolè College. Secondary schools and gymnasiums occasionally provide venues for MTAU activities. The cultural house provides a venue for MTAU's large events and the hospital provides a venue for some of the lectures on healthy lifestyles. Nevertheless, ties with the VET schools of Marijampole are not strong. This has been confirmed by both the TAU and the VET school respondents. Both sides mentioned that co-operation could come about if the other side would show the initiative.

- Other civic and community organisations in Marijampolè. MTAU co-operates with other organisations representing older people, adults, associations providing services for youth and children, as well as youth-led organisations. It co-operates in activities and competes for municipality funding with another main organisation for older people, the Lithuanian Pensioners Union "Bočiai". MTAU also collaborates with other adult organisations, as some of its deans and students are also leaders or members of other organisations in Marijampolè. For example, the Arts faculty has common activities for adults at the Women's crisis center, Day Center of Patašine, etc. (See more in the case of Ms Lidija). MTAU promotes inter-generational dialogue as it occasionally co-operates on common events with the MarijampolèYouth Organisations' 
Board "Round-table", in particular, Marijampole’s Chapter of Young Socialdemocrats and holds activities for children at the local orphanage.

\section{Implementation mechanisms}

Funding and costs

- The composition of MTAU funding. Permanent sources of funding account for $45 \%$ of overall funding. These sources include membership fees and $2 \%$ of income tax, which can be allocated by any person to any organisation or institution. The membership fee of EUR 20 for 2 years per person makes up 35\% of funding. The remaining 10\% comes from the income tax allocated to MTAU. Project funding makes up 50\% of the total funding. On a regular basis, MTAU applies for Marijampolè's Municipality Funds and National funds. The remaining 5\% comes from ad hoc sources, such as donations from local companies and entrepreneurs. Occasionally, MTAU students sell their handicrafts and contribute some of the revenue to the MTAU.

- The composition of MTAU costs. Analysis of MTAU costs shows that the organisation relies heavily on the volunteering and goodwill of lecturers and private donors. MTAU does not pay for the rent of its venues thanks to its co-operation with various institutions. The majority of MTAU funding is allocated to cover transportation costs as MTAU students travel to participate in various events outside the city of Marijampolè. MTAU usually suggests covering the travel costs of lecturers from other towns, but often they do not require reimbursement. In addition, there are no administrative or organisational costs, as all staff, including the accountant, as well as deans and student representatives, work voluntarily. Some deans occasionally get paid for delivering training as part of the project activities.

\section{Governance}

The governing bodies have developed organically within MTAU, to represent the needs of students and lecturers (See Figure 9). They were not outlined in the Statute of MTAU.

Figure 9: The governance structure of MTAU

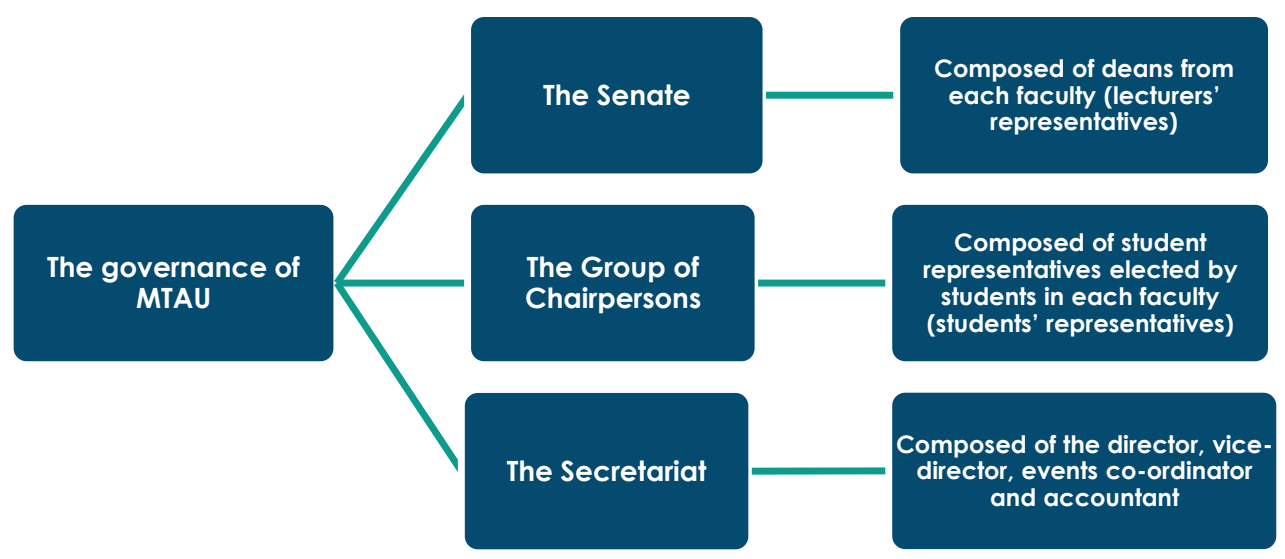

Source: prepared by Visionary Analytics based on MTAU data. 


\section{Activities}

The educational activities are organised within faculties. The number of faculties has increased from 5 in 2005 to 16 in 2015 (see Table 2). As of 2015, the most popular were the Psychology and Healthy Lifestyle faculties. The students are awarded with the Diploma after receiving 40 credits. The attendance of MTAU is obligatory.

\section{Table 2. Attendance of MTAU faculties}

Nr.

$$
\text { Faculty }
$$

$$
\text { Faculty of Psychology }
$$

2. Faculty of Healthy Lifestyle

3. Faculty of Household Activities

4. Faculty of Spiritual Advancement

5. Faculty of Environment Protection

6. Faculty of Style and Fashion

7. Faculty of Law

8. Faculty of Information and Communication Technologies (ICT) ${ }^{\star}$

9. Faculty of Culture and Art

10. Faculty of Fine Arts

11. Faculty of Handicrafts

12. Faculty of Political Discussions

13. Faculty of Languages:**

$$
\text { English }
$$

German

French

14. Faculty of Physical activity and Physiotherapy

15. Faculty of Music

16. Faculty of Literature

* The faculty has not taken on any students in 2015 due to the inconvenient venue for its classes, outside the town of Marijampolè. However, the Faculty has not been abolished and it is intended to restart activities in the 2015/2016 academic year.

** Lectures in foreign languages are organised once a week, thus the two year programme is completed during one year. It takes 40 academic hours and costs only EUR 20 for one year. There are five different levels available within each language. There are 26 English language students: $10-\mathrm{A}$ level, $11-\mathrm{C}$ level and 5 $\mathrm{D}$ level (respectively $-1^{\text {st }}, 3^{\text {rd }}$ and $4^{\text {th }}$ years). Currently there are $85^{\text {th }}$ year students attending the German language course. French language was abolished due to lack of interest

Source: Prepared by authors based on MTAU data

There is a slight difference between activities organised in MTAU - intensive (once a week) and extensive courses (once a month), as well as ad hoc events:

- Studies in all of the theory-oriented faculties and some of the practical faculties are extensive. It takes two consecutive years to earn 40 credits. The activities in these faculties take place at least once a month, during working time. Classes usually take about two academic hours. There are lectures, workshops, and discussion groups organised during the activities.

- The skills-oriented faculties of ICT and Foreign Languages are intensive. The classes are held each week, or each second week. The 40 credits are earned during one year. 
- Ad hoc events are organised when important people visit MTAU, there are traditional celebrations held, or trips organised. These are mainly social events.

The faculties of Arts, Crafts, Foreign Languages, ICT, Healthy Lifestyle and Psychology will be included in the further analysis, as MTAU students found these faculties the most useful for their entrepreneurial activities and for their longer participation in the labour market.

\section{Challenges and successes in providing relevant skills/knowledge}

MTAU is experiencing various challenges in promoting longer working lives and providing labour market related skills for older people in Marijampole. The strategic, financial, operational, physical capacity, psychological and legal challenges are discussed below.

- Strategic: Lack of understanding of the role of MTAU in providing labour market skills for older workers. Overall, the respondents said the main purpose of MTAU is to spend quality time with other older people. Thus, the promotion of labour market skills is not perceived as the main objective of MTAU, but as a positive side effect.

- Financial: MTAU is dependent either on project grants or on the goodwill of deans/lecturers and private companies. As of 2015, six out of 15 faculties focus on skills: ICT, Foreign Languages, Arts, Crafts, Music, Physical activity and Physiotherapy. It is difficult to ensure continuous practical training when the teachers are not paid. Such training depends on the commitment of individuals. For example, the ICT faculty no longer exists as the dean moved to Vilnius.

- Physical capacity: the high-number of students attending MTAU poses challenges for the organisers. It is increasingly difficult to find large enough venues, to provide quality training and to organise transportation. For example, the dean of Healthy Lifestyle and Physical Activity and Physiotherapy had to limit the number of students, as the sports hall could not accommodate all those interested.

- Psychological: The mind-set of MTAU students about entrepreneurial activities. The majority of students attending the Arts and Crafts faculties are not willing to sell their items. In addition, MTAU students feared that they are "too old to take risks and to make money". Some of them mentioned a "shame" of selling their crafts. This is still regarded as a last resort to earn money.

- Legal: Some Lithuanian laws and policies are hindering silver entrepreneurship. As well as psychological barriers, people are afraid to lose their disability allowances, pensions or reduced tax tariffs for central heating if they are engaged in entrepreneurial activities. Current laws state that if a person is engaged in economic activity, he/she should not get state support. This clause hinders the level of entrepreneurial initiatives among older people. Alternatively, they turn to the grey economy.

Despite the above-mentioned challenges certain successes of MTAU should be highlighted:

- A lifelong learning approach is taken by both lecturers and students. Even if some of the MTAU students claimed that it is too late to start businesses, they all agreed that it is never too late to start learning something new. The most important aspect is that they learn how to learn. This is reflected in the case studies. 
- Deans are searching for ways to promote entrepreneurship. The dean of Crafts is looking for the most suitable ways to sell the crafts made by women. For example, she noticed that women are keen to sell their crafts outside of Marijampole, thus she is willing to participate in the markets of the neighbouring town festivals.

- Lectures are based on the demands and needs of students. All deans interviewed said that they find out what students are interested in before suggesting topics. In addition, they deliver information in a manner that is practical and "user-friendly". For example, the dean of Physical Activity and Physiotherapy shows that exercises do not require additional equipment. The dean of ICT teaches how to declare taxes online or how to book a visit to the doctor online.

- Knowledge exchange with family members. One of the MTAU students said that family members are "remote" students of MTAU as older people willingly pass on their skills and knowledge to their children and, especially, to their grandchildren.

\section{Estimated impacts (as well as monitoring and evaluation methods if any), including possible long-term effects}

The mini case studies in the boxes below illustrate some specific effects of MTAU in developing new skills to promote longer working lives and entrepreneurship among older people. The common denominator for all these skills would be that MTAU provided some basic skills and inspired students to practice on their own in order to develop these skills. Thus, the meta-competence of learning how to learn was acquired or harnessed in MTAU.

Whereas the majority of MTAU students apply these skills for their own personal needs (i.e. using ICT skills, such as writing e-mails to their children, using Skype etc.), the cases provided below show how foreign language, ICT and handicrafts courses enabled both entrepreneurial activities and longer working lives of those already in employment.

Box 2. Experiences from participants in Marijampolè's Third Age University

\section{Ms. Albina (69 years old) - German language skills leading to prolonged employment}

Ms. Albina joined MTAU eight years ago, when she was 61 years old. She signed up to the faculties of Spiritual Advancement, Healthy Lifestyle, Physical Activity and Physiotherapy and took classes in German language. The latter was especially beneficial. Ms. Albina prolonged her working life up until the age of 65 , as she went to Germany to work as a personal care worker for elderly people. She managed to use other knowledge gained at MTAU while caring for elderly people, as she also used physiotherapy and physical activity exercises. In Germany, Ms. Albina further studied on her own and improved her German language skills. Ms. Albina knows several other women over 50, who have also learnt German and English at MTAU and went to care for elderly people in Germany, the UK or Ireland. She says that all the experience gained in MTAU can be applied in practice; it just depends on personal motivation. The respondent stressed her motivation to continue learning.

\section{Ms. Lidija (72 years old) - Handicrafts leading to entrepreneurship and exchange of knowledge among generations}

Ms. Lidija joined MTAU at the age of 64 . She immediately registered at the Faculty of Arts, as she felt connected to this subject. During seven years at the Faculty of Arts, she learnt silk painting, making crafts from leather, wool felting, decoupage, clay modelling, etc. Thus, she made many items, but gave the majority of them away as gifts to her family and friends. However, occasionally she sold some of her items on the MTAU stand at the markets during city festivals. Now Ms. Lidija cannot make handicrafts due to health reasons, but she still teaches younger people how make handicrafts. For example, she trained women attending the Women's Center and also children with fewer opportunities at the Child Day-Care Center how to felt wool. Ms. Lidija explains that her participation in MTAU 
improved her life satisfaction and covered expenses for materials used for her hobby.

Mr. Albinas (close to 70 years old) - ICT skills leading to entrepreneurship

Mr. Albinas joined the MTAU ICT faculty two years ago. At that time, he was a farmer of 67 years of age with only basic ICT skills. However, he was eager to learn how to use a content management system during the course. Afterwards, he created and published a website as he planned to sell his agricultural products - vegetables, meat, etc. in an online shop. The ICT dean was very proud of such determination and commitment to use the knowledge gained at MTAU.

Source: Author's interviews with participants and the dean of the ICT faculty

\section{Sustainability of the initiative}

The activities of MTAU have certain advantages in terms of their sustainability. MTAU itself has become a trend among older people in Lithuania. Thus, older workers can be reached in this way. In addition, MTAU and other TAUs have accumulated certain intellectual capital, including:

- Human capital - devoted secretariat, experienced deans, loyal student representatives;

- Organisational capital - governing structures and decision making processes, methods of working in different faculties;

- Relational capital, which is especially strong - co-operation and collaboration with local government, institutions and civil society organisations.

Strong organisational and relational capitals indicate that activities at MTAU are not time-bound or project-based, but ongoing and foreseeable. Therefore, ICT courses at MTAU are different from the onetime project-based on Marijampole Public Library's initiative (see box 5) In addition, the deans of MTAU know how to provide information and engage with older people.

The sustainability of MTAU activities in the field of providing labour market skills could be ensured via further financial and institutional means.

- Institutional. MTAU has not yet institutionalised its role in promoting longer working lives among its strategic goals. In this way, MTAU and other TAUs could become partners of governmental institutions and initiatives addressing the ageing workforce in Lithuania.

- Financial. The MTAU example showed that its activities depend heavily on project grants and the dedication and commitment of MTAU deans. The case of MTAU's ICT course, which was stopped for a while due to the dean moving away from Marijampole, highlights this issue and shows that it is difficult to replace deans, especially those providing intensive courses. Therefore, additional financing would be needed, in order to ensure sustainability in providing skills such as ICT and foreign languages. 


\section{Box 3. Intensive ICT training for older people in the Marijampole PublicLibrary}

In 2011, the Marijampole Public Library organised intensive ICT training for older people. This course was different from that of the MTAU ICT Faculty as it was held as a one-time event. The initiative was part of the wider project "Window to the Future", which promotes better internet coverage across Lithuania. "Window to the Future" is an alliance of Lithuanian companies calling for the establishing of public internet access points across the country and dedicated to teaching people how to use computers and the internet.

This training project was implemented by public internet access points in parishes, Libraries, municipalities, etc. and promoted ICT competences among older people by enabling them to use computers and the internet at the abovementioned access points. It was oriented towards the personal needs of older people, rather than promoting their labour market skills. The partners involved were MTAU and the Territorial Labour Exchange Office of Marijampolè.

The intensive training took one working week (five days), four hours per day. The training was implemented in the town of Marijampole - at the Marijampole Public Library. In addition, subsequent training was carried out in the rural areas of Marijampolè - at the rural offices of the Marijampole Public Library.

The training met several difficulties as a result of the wide differences in the ages and motivations of students. Some of the attendees were over 70 years of age and came mainly to spend time socialising, whereas others were older workers sent by their employers, to improve their ICT skills. They were motivated to achieve the certificate at the end of the training. In addition, some people attending the training did not have a personal computer while others had a computer but did not have internet access. For such students, the training content became more theoretical rather than practical. There were also different purposes for using the computer and different skills levels. The course was adapted to the needs of the students - thus trainers had to provide a wide range of information e.g. how to use and take care of a computer, how to behave in social networks, how to use Skype, how to send emails, how to count with Excel etc.

Nevertheless, despite these difficulties participants in the training were particularly satisfied. Below are two mini case studies of Ms. Zena and Ms. Birute, who attended the training. Ms. Zena is in employment, working for a governmental agency, whereas Ms. Birutè is an entrepreneur using online marketing:

- Ms. Zena (58 years old) learnt how to apply the ICT skills in her job. She works in a public institution where up to date ICT skills are essential. Ms. Zena wanted to learn more about how to use Excel and PowerPoint, as she was not feeling confident in using these programmes. Therefore, she registered for the intensive courses that were provided by the Marijampole Public Library. The courses were held for one week in December 2011. Ms. Zena said she was pleased with the quality and the results of this training. She was feeling more comfortable with tasks within her job. In addition, Ms. Zena attended other courses on computer literacy.

- Ms Birutè (58 years old) is a self-employed entrepreneur using ICT skills for the promotion of her products. Ms. Birute sells health-related products via a network marketing scheme. Two years ago, she participated in the ICT course organised by the Marijampole Public Library. At that time, she was unemployed. Ms. Birute already had some basics as she was working with computers in her previous employment. During the course, she learnt how to work with Excel. After the course, she felt more comfortable using the computer on her own. Ms. Birute bought a computer after she became a manager of the distributors at the company. Currently, she uses social networks in order to find other distributors and clients, and also for her personal needs.

This initiative to train adults and older people in ICT skills has had a strong added value for some participants. One of the major weaknesses was that the courses were held as one-off initiative. This did not provide opportunities for people to become more advanced. Finally, there was another project-based initiative on ICT training by the Union of Retired Persons in Lithuania "Bočiai". However, it also focused on older people using computers for personal aims.

Source: Interviews with the head of the Information Department at the Marijampole Public Library; Ms. Birute and Ms. Zena, who attended ICT training at the Marijampole Public Library. 
Both case studies break the misconceptions that it is not efficient for companies to invest in older employees and that it is not necessary for older people to invest in their own skills. These examples of local initiatives had a positive impact on prolonging the working lives of older people, from extending their regular employment to engaging in entrepreneurship:

- The activities of the MTAU Faculties of ICT, Foreign Languages, Arts and Handicrafts had the most significant positive impact on the promotion of longer working lives and entrepreneurial initiatives among older workers. However, the prolongation of working lives was not the intended aim and is not included under the main aims of MTAU, which is primarily regarded as a place for older people to socialise. The respondents reported that they have harnessed the metacompetence of learning how to learn. The MTAU students interviewed were interested in the content of the lectures. Some of them found an opportunity to apply the knowledge in their working lives, others started entrepreneurial activities. In turn, MTAU has accumulated special knowledge on how to work with older people. However, MTAU relies heavily on the idealism of the deans providing these courses voluntarily. In addition, half of MTAU's income is projectbased funding. This can have negative implications for the continuity and stability of the initiative vis-a-vis changing priorities of funds, and therefore their impermanence.

- Intensive ICT training for older people was delivered by the Marijampolè Public Library. This one-off initiative was part of the national project "Window to the Future". Participants were both in employment and retired. Such a mixed group raised challenges for trainers to make the training interesting and understandable for everyone. The ICT courses had a shorter duration and required less resources than, for example, the MTAU ICT faculty activities, which lasted for one year, twice a month. However, the continuous MTAU education model is more sustainable in terms of learning outcomes and can be better accessed by retired people in Marijampole. On the other hand, the MTAU model is harder to replicate, as it would require more efforts and resources than one-off intensive ICT courses. 


\section{CONCLUSIONS AND RECOMMENDATIONS}

This paper has highlighted the importance of local economic strategies to tackle the challenges of a rapidly shrinking and ageing labour force in Lithuania. Whereas there are some relevant policy measures at the national level, activity at the regional and local levels remains limited. The territorial labour exchange offices are exceptions to this rule, as they provide the training and support for skills acquisition for older unemployed people. In this mission the labour exchange offices co-operate with educational institutions colleges, VET schools, and labour market training centres (LMTCs). Other local initiatives are rare in Lithuania. Therefore, MTAU, as well as the one-off initiative of the Marijampole Public Library, can be considered as good practice examples that can be replicated elsewhere. The continuous MTAU education model proved to be more sustainable than the one-off initiative.

The case study has identified the following recommendations that are aimed at national and regional/local policy makers as well as training providers.

National policy makers have identified the need to prolong working lives. However, they still should include more practical measures in Active Ageing strategies for older people to acquire the relevant labour market skills. They should fix contradicting policies, for example, by enabling entrepreneurial activities among older people and allowing them to maintain tax benefits or subsidies if a certain income threshold is not reached. National policy makers should highlight the importance of training and re-training in an ageing society. This could be reflected in the allocations of ESF funds towards the skills development of older workers. Policy makers could also acknowledge and promote the role of Third Age Universities in providing the labour market skills for older workers. In particular, governmental initiatives could finance some activities of TAUs that contribute to the implementation of the Active Ageing Strategy. For example, at least token compensation for people engaged in TAU activities on a permanent basis could be foreseen, especially for those providing intensive and labour market relevant courses, such as ICT, foreign languages, and crafts.

Regional and local policy makers should also take a lead in implementing active ageing strategies. Municipalities or regions could promote the best examples among employers in employing older workers. They could also promote good practices and encourage employers to send their older employees to labour market-relevant training courses. Local and regional policy makers are best suited to co-ordinate the efforts of formal and non-formal training providers in the regions, so that the synergies are better exploited. They could start by promoting dialogue between the two sides. Local policy makers could ensure that one-off project based initiatives are supplementing, but not replacing, the relevant continuous trainings/initiatives.

The TAUs are both objects and stakeholders of active ageing policies. The case study revealed that MTAU has still to understand its role in promoting longer working lives in the context of a rapidly ageing workforce in Lithuania, and in the Marijampole region in particular. MTAU should target older people willing to remain in employment. This could further help to institutionalise TAUs and ensure sustainable funding from the state budget. In addition, MTAU should organise some of its activities online in order to solve the physical capacity challenge. For example, MTAU could use massive open online courses 
(MOOCs) for their public lectures or Moodle system ${ }^{2}$ to provide training (e.g. for advanced ICT faculty students). MTAU should actively promote and enable silver entrepreneurship by providing means to sell handicrafts made by its students (i.e. social economic or social entrepreneurial activity). Finally, MTAU should provide advice on obstacles and barriers to the promotion of entrepreneurial initiatives among older people (i.e. lifting current clauses hindering economic activities of people with disabilities, retirees etc.).

The Marijampole Public Library, which has organised one-off ICT training for older people could, first of all, ensure the continuity of the intensive ICT courses for older people and/or provide ICT courses on a regular basis as a service of the Public Library. In this mission, the Library could co-operate with MTAU in addressing the physical, financial and other age-specific challenges of older people. In addition, it would be beneficial for the course provider to differentiate between beginners and intermediate users during the ICT training. The training provider could contact the employers who need to upgrade the ICT skills of their older workers.

\footnotetext{
${ }^{2}$ Moodle system - is open source learning platform (i.e. https://moodle.org/).
} 


\section{BIBLIOGRAPHY}

Ackers, L., \& Dwyer, P. (2002), Senior citizenship? Retirement, migration and welfare in the European Union, Policy Press

Adults Education Centre of Plungè (2011), The retraining labour force - a path to active ageing, Plungè.

European Commission (2015), Country Report Lithuania 2015, COM (2015) 85 final, Brussels, Commission Staff Working Document SWD (2015) 34 final

European Commission (2012), "The 2012 Ageing Report: Economic and budgetary projections for the 27 EU Member States (2010-2060)", European Economy 2:2012, Directorate-General for Economic and Financial Affairs of the European Commission.

EU Support website (2011), Development of Adults' education system by providing learners with the general competencies (phase - II), http://www.esparama.lt/paraiska?id=32448\&pgsz=10.

Eurostat (2013), European Population Projection of the base year 2013 - EUROPOP 2013

European Social Fund (2014), http://www.esf.lt/lt/news/view/id.1399/

European Social Partnership Network (2015), PAR-2015 Pensions Country Profile

Government of the Republic of Lithuania (2015), The list of projects of legal acts, which are requested to be included in the Working Programme during VI Session (Spring) of the Parliament of the

Republic of Lithuania, Resolution of Government of 18 of February, No. 166. https://www.etar.lt/portal/lt/legalAct/87f06470bc3311e487a3c49dd729baa4

Kalvaitis, A., Barauskienė J. \& Mačènaitè A. (2014), Third Age Universities in Lithuania: Analysis of the Situation and Opportunities for Advancement, Education Advancement Center, Vilnius.

Lithuanian Labour Exchange Office (2015), http://www.ldb.lt/Informacija/ESParama/Puslapiai/vyresnio amziaus bed remimas.aspx

Medardas Čobotas TAU (1995), Statute of Medardas Čobotas TAU

MTAU (2007), Statute of MTAU

MTAU (2015), Marijampole's TAU Strategy, 2015

MIPEX (2014), Migration Integration Policy Index by the Migration Policy Group. http://www.mipex.eu

Ministry of Social Security and Labour of the Republic of Lithuania (2014), The Social Report 20132014, Vilnius. 
Minister of Social Security and Labour of the Republic of Lithuania (2014), Order of implementation of National Demographic (Population) Policy Strategy in the Field of Family Welfare 2014-2015 Action Plan of 14 of April, 2014, No. A1-209.Vilnius.

Republic of Lithuania (2002), Labour Code of the Republic of Lithuania as last amended on 9 December 2010 - No XI-1219, approved by Law No IX-926 of 4 June $2002 .<$ http://www3.Irs.lt/pls/inter2/dokpaieska.showdoc_e?p_id=391385>

Republic of Lithuania (2009), Law on Support for Employment, date version of $1^{\text {st }}$ of August, 2009.

Republic of Lithuania (2014), Operational Programme for the European Union Funds' Investments in 2014-2020.

Social Model (2015), Social Model Report, http://www.socmodelis.lt/wp-content/uploads/Modelioataskaita.pdf

Zabarauskaite R. \& Blaziene I. (2013), Lithuania: The role of governments and social partners in keeping older workers in the labour market, Eurofound Observatory: EurWORKTopic: Published on: 02 June 2013. http://eurofound.europa.eu/observatories/eurwork/comparative-information/nationalcontributions/lithuania-the-role-of-governments-and-social-partners-in-keeping-older-workers-inthe-labour-market. 


\section{LIST OF PEOPLE INTERVIEWED}

1. $08 / 03 / 2015$ - The Director of MTAU

2. $08 / 03 / 2015$ - The head of the Information Department at the Marijampole Public Library

3. 08/03/2015 - The administrator of the Department of Training of Construction and Mechanics, at the Vocational Training Center of Marijampole

4. 08/03/2015 - Officer responsible for Adult Education at the Department of Education, Municipality of Marijampolè

5. 08/03/2015 - Project co-ordinator of the Support for older unemployed persons in the Territorial Labour Exchange Office of Marijampole

6. 09/03/2015 - Ms. Birute, who attended ICT training at the Marijampolè Public Library

7. 09/03/2015 - Ms. Zena, who attended ICT training at the Marijampole Public Library

8. 09/03/2015 - Officer at the Department of Information Resources, Territorial Labour Exchange Office of Marijampole

9. 09/03/2015 - Dean of the Faculty of Psychology, MTAU

10. 09/03/2015 - Dean of the Faculty of Handicrafts, MTAU

11. 09/03/2015 - The foreperson of the Faculty of Arts, MTAU

12. 12/03/2015 - Ms. Albina, student of German language and Physiotherapy at MTAU

13. 12/03/2015 - Ms. Lidija, student of Arts at MTAU

14. 12/03/2015 - Student of English language at MTAU

15. 12/03/2015 - Dean of the Faculty of Arts, MTAU

16. 12/03/2015 - Dean of the Faculty of Healthy Lifestyle, MTAU

17. $25 / 03 / 2015$ - Dean of the Faculty of ICT, MTAU

18. 25/03/2015 - Student Nr. 1 of ICT at MTAU

19. 26/03/2015 - Student Nr. 2 of ICT at MTAU

20. 26/03/2015 - Specialist at the Meilès Lukšienès Education Center of Marijampolè

21. 26/03/2015 - Co-ordinator at the Center of Continuing Studies, Marijampole College

22. 26/03/2015 - Vice-director for Education Affairs at Marijampolė College 
This paper was prepared by Simonas Gaušas and Lina Vosyliūtė under the supervision of Nathalie Cliquot, Policy Analyst at the OECD LEED Programme.

Simonas Gaušas is Partner and Research Manager at Visionary Analytics. With more than 10 years experience in impact assessment, policy evaluation and applied research, Simonas focuses on education (especially VET, adult learning and education financing) and labour market policies (especially greening effects on jobs, sectoral labour market trends and anticipation of skills needs). He is well experienced in successfully managing large European assignments, report writing, field research, and technical assistance and actively contributes to relevant international conferences, workshops and study visits. Simonas is an active participant in ReferNet Lithuania network on the development of vocational education and training and European SkillsNet network on forecasting labour supply and demand in Europe.

Lina Vosyliūtė works as a researcher at Visionary Analytics. Since 2002, Lina has worked in the field of active citizenship and migration as well as non-formal and informal education and training and social inclusion policies. She has published academic and policy papers on Common EU Asylum Policy, future of Home Affairs policies, Migrant rights and other topics. Lina's experience includes qualitative methods, such as comparative analyses, interviews, focus groups, study cases and quantitative methods, such as surveys, used in studies and evaluations, consultations for national ministries and their agencies. Clients include international organisations, such as the European bodies, national authorities and institutions. 